\title{
In vitro bacteriostatic effects of Polymyxin B combined with Propofol medium and long chain fat emulsion injection against Escherichia coli
}

\author{
Lei Qi ${ }^{1,2 \#}$, Yue Wang ${ }^{1 \#}$, Bairong Chen ${ }^{3}$, Yuting Ren ${ }^{1}$, Guomin Mao ${ }^{1}$, Guiwen Liang ${ }^{1}$, Wei Liu ${ }^{4}$, \\ Yang Zhou ${ }^{4}$, Zhongwei Huang ${ }^{1}$, Kai Sun ${ }^{5}$, Haiyan Jiang ${ }^{1}$ \\ ${ }^{1}$ Department of Emergency Medicine, Affiliated Hospital of Nantong University, Nantong, China; ${ }^{2}$ Rugao Branch (Rugao Bo'ai Hospital), Affiliated \\ Hospital of Nantong University, Nantong, China; ${ }^{3}$ Department of Medical Laboratory, School of Public Health, Nantong University, Nantong, \\ China; ${ }^{4}$ Department of Obstetrics and Gynecology, Affiliated Hospital of Nantong University, Nantong, China; ${ }^{5}$ Department of Emergency \\ Medicine, The First Affiliated Hospital of Nanjing Medical University, Nanjing, China \\ Contributions: (I) Conception and design: H Jiang, Z Huang, K Sun; (II) Administrative support: L Qi, Y Wang; (III) Provision of study materials or \\ patients: G Liang, W Liu; (IV) Collection and assembly of data: G Mao; (V) Data analysis and interpretation: Y Ren; (VI) Manuscript writing: All \\ authors; (VII) Final approval of manuscript: All authors. \\ \#These authors contributed equally to this work. \\ Correspondence to: Haiyan Jiang; Zhongwei Huang. Department of Emergency Medicine, Affiliated Hospital of Nantong University, 20 West Temple \\ Road, Nantong 226001, China. Email: jhy@ntu.edu.cn; tdfyhuangzw@163.com; Kai Sun. Department of Emergency Medicine, The First Affiliated \\ Hospital of Nanjing Medical University, Nanjing, China. Email: sunkai@njmu.edu.cn.
}

Background: Polymyxins is a class of cyclic polypeptide antibiotics with strong antibacterial activity against Gram-negative bacteria. However, bacteria become resistant to Polymyxins. Thus, Polymyxin B (PMB) in combination with other antimicrobials may be a better choice in clinic. This study aimed to evaluate the synergistic bacteriostatic effect of PMB combined with Propofol medium and long chain fat emulsion injection against Escherichia coli in vitro.

Methods: The Minimal Inhibitory Concentration of Polymyxin B combined with Propofol medium and long chain fat emulsion injection and two drugs used alone against Escherichia coli were detected with the Kirby-Bauer disk diffusion (K-B) method, and the diameter of the inhibition zone was calculated to evaluate bacteriostatic effects.

Results: Different concentrations of PMB all had obvious bacteriostatic effects on Escherichia coli, while different concentrations of Propofol medium and long chain fat emulsion injection had no bacteriostatic effects on Escherichia coli. The bacteriostatic effect of the combination of PMB with Propofol medium and long chain fat emulsion injection against Escherichia coli was synergistic, and no effects of uncorrelated and antagonism were observed in this combination.

Conclusions: PMB combined with Propofol medium and long chain fat emulsion injection can improve the bacteriostatic effect for Escherichia coli in vitro.

Keywords: K-B method; Polymyxin B (PMB); Propofol medium and long chain fat emulsion injection; bacteriostatic effect; Escherichia coli

Submitted Feb 23, 2021. Accepted for publication Apr 21, 2021.

doi: 10.21037/apm-21-751

View this article at: http://dx.doi.org/10.21037/apm-21-751 


\section{Introduction}

Antibiotics are regarded as "miracle drugs" for the treatment of bacterial infection, but the cheaper availability of antibiotics has become common all over the world (1). Inappropriate and uncontrolled use of antibiotics finally leads to bacterial resistance, which is a major problem in the fight against life-threatening bacterial infections $(1,2)$. Escherichia coli is a Gram-negative bacterium, which belongs to ESKAPE (Enterococcus faecium, Staphylococcus aureus, Klebsiella pneumoniae, Acinetobacter baumannii, Pseudomonas aeruginosa and Enterobacter species) group of pathogens, and causes serious infection (3). Nowadays, the growth rate of multi-drug resistance among Enterobacteriaceae is faster than previously thought, leading to a high global mortality (4) and bringing a significant medicine challenge. However, the development of new antibiotics, particularly those anti-Gram-negative bacteria agents, moves along at a slow pace. In the past decade, only dozens of new antimicrobials have been produced. Among these antimicrobial, except for tigecycline, only polymyxins still supports high antibacterial activity for multi-drug resistant (MDR) Gram-negative bacteria (5). Data (6) shows Polymyxins is a class of cyclic polypeptide antibiotics with strong antibacterial activity against Gram-negative bacteria. However, bacteria are becoming resistant to the last resort of Polymyxins, so that it limits the options of clinical treatment for serious infections (4). Thus, to effectively control serious infections caused by MDR Gramnegative bacteria, the combination of antibiotics may be a better choice. It has been demonstrated that polymyxinsbased combined with several antibiotics has synergy against MDR Acinetobacter baumannii, MDR Pseudomonas aeruginosa, Klebsiella pneumoniae, carbapenemase-producing K. pneumoniae et al. in vitro (7-9). However, few studies have evaluated the activity of polymyxin B combinations against Escherichia coli. Polymyxin B (PMB) in combination with other antimicrobials is indeed considered a reasonable and safe treatment possibility for MDR Gram-negative pathogens (10) and endotoxin shock (11).

Polymyxins is an old drug that belongs to polypeptides, including Polymyxin A, B, C, D and E. Polymyxins exerts their bacteriostatic effect by damaging the membrane of the bacterial cell. Polymyxins is selectively targeted at the three-domain lipopolysaccharide (lipid A, oligosaccharide, and $\mathrm{O}$-antigen), which is the main component of the outer membrane of Gram-negative bacteria $(12,13)$. This lipopolysaccharide (LPS) has several negative charges with which polymyxins can bind by electrostatic interactions. This binding competitively replaces membrane-stabilizing ions, such as $\mathrm{Ca}^{2+}$ and $\mathrm{Mg}^{2+}$, thereby destabilizing the lipopolysaccharide layer and allowing the introduction of the polymyxins hydrophobic chain into the hydrophobic domain (lipid A). As a result, the permeability of the outer membrane increases and the polymyxins penetrates into the periplasmic space. In the periplasmic space, polymyxin forms contacts between the outer and internal membranes and promotes the fast and selective exchange of anionic phospholipids. This, in turn, causes an osmotic imbalance and ultimately the death of the bacteria $(14,15)$. PMB, one of the clinical available polymyxins, plays an increasingly important role in clinics because it is a "last-line" of defense against Gram-negative 'superbugs' (16). Simultaneously, the other data (17) also show the combination of $\mathrm{PMB}$ with lysophosphatidylcholine (LPC) can cause the bacterial membrane porous, leading to the degradation of the folding protein regulator dank and finally cause the bacterial cell membrane to collapse, further resulting in bacterial death.

Propofol (2,6-diisopropyl phenol), as a general intravenous anesthetic, is widely used in clinical practice because this highly lipophilic agent has a fast onset and short, minimal side effects and predictable duration of action due to its rapid penetration of the blood-brain barrier and distribution to the CNS (18). More than that, Propofol is a potent antioxidant, has anti-inflammatory properties. As a consequence of these properties propofol is being increasingly used in critically ill septic patients (19). Since propofol is water insoluble and has high liposolubility, it is necessary to add emulsifiers including lecithin to prepare fat emulsions for clinical application (20), then Propofol medium and long chain fat emulsion injection has arose at the historic moment. As a new type of drug-loaded fat emulsion injection, it consists of propofol, soybean oil, egg yolk lecithin and glycerol (21). Owing to partial hydrolysis of egg yolk lecithin may occur during placement, Propofol medium and long chain fat emulsion injection contains LPC and lysophosphatidylethanolamine (LPE), et al. (22). As noted above, the combination of PMB with LPC can finally result in MDR Gram-negative bacterial death. Therefore, a bold assumption is put forward that whether PMB combined with Propofol medium and long chain fat emulsion injection has synergistic bacteriostatic effect against Escherichia coli in vitro.

The purpose of this study was to observe the inhibitory effect of PMB alone or PMB combined with Propofol medium and long chain fat emulsion injection on Escherichia 
coli and to determine whether the combination of the two drugs synergically expanded the bacteriostatic effect of a single drug to supply a certain theoretical basis for clinical rational drug use. We present the following article in accordance with the MDAR reporting checklist (available at http://dx.doi.org/10.21037/apm-21-751).

\section{Methods}

\section{Test strain}

The standard strain of Escherichia coli (ATCC25922) was derived from ATCC in the United States.

\section{Drugs and reagents}

PMB (National Medicine Permission Number H31022631) was purchased from Shanghai Shangyao First Biochemical Pharmaceutical Co., Ltd; Propofol medium and long chain fat emulsion injection (National Medicine Permission Number H20143355) was purchased from Guangdong Jiabo Pharmaceutical Co., Ltd; Phosphate Buffered Saline (PBS): $7.9 \mathrm{~g} \mathrm{NaCl}, 0.2 \mathrm{~g} \mathrm{KCl}, 1.44 \mathrm{~g} \mathrm{Na}_{2} \mathrm{HPO}_{4}$, and $1.8 \mathrm{~g}$ $\mathrm{K}_{2} \mathrm{HPO}_{4}$ were weighed and dissolved in $800 \mathrm{~mL}$ distilled water, then $\mathrm{HCl}$ was used to adjust the $\mathrm{pH}$ value of the solution to 6.0 , finally distilled water was added to adjust the volume to 1L; Dimethyl Sulfoxide (DMSO) was purchased from Shanghai Titan Scientific Co., Ltd.

Preparation of standard concentration of bacteria liquid First, the standard strains of Escherichia coli were inoculated and cultured in a nutrient agar medium (23). Second, two colonies were inoculated in a $10-\mathrm{mL}$ liquid medium; then, the processed liquid medium was incubated and shaken at $37^{\circ} \mathrm{C}$ for 8 hours. Last, the harvested bacterial liquid was diluted with the liquid medium at 1:9, and the diluted bacterial liquid was inoculated as soon as possible (within 15 minutes).

\section{Preparation of stock solution of PMB}

The stock solution of PMB $(50 \mathrm{mg} / \mathrm{mL})$ was prepared with pH 6.0 of PBS.

\section{Preparation of stock solution of Propofol medium and long chain fat emulsion injection \\ The stock solution of Propofol medium and long chain fat emulsion injection $(10 \mathrm{mg} / \mathrm{mL})$ was prepared with $0.1 \%$ DMSO and the $\mathrm{pH} 6.0$ of PBS.}

\section{Procedures for the determination of minimum} inhibitory concentration (MIC)

The circular filter paper of $6 \mathrm{~mm}$ was sterilized by ultraviolet for 1 hour and stored aseptically. The K-B method was finally used, referring to the related literature (24). The specific methods were as follows.

\section{Dilution of stock solution of PMB}

The stock solution of PMB $(50 \mathrm{mg} / \mathrm{mL})$ was diluted with $\mathrm{pH}$ 6.0 of PBS. According to the breaking point concentrations of sensitivity and drug resistance of Polymyxins that Clinical and Laboratory Standards Institute (CLSI) recommend were $\leq 2 \mathrm{mg} / \mathrm{L}$ and $\geq 4 \mathrm{mg} / \mathrm{L}$, respectively (25), the concentrations of PMB were set. Firstly, nine $1.5 \mathrm{~mL}$ Eppendorf (EP) tubes were taken out, and each tube was filled with a PMB solution of $0.1 \mathrm{~mL}$. One tube was taken out for later use, and others were frozen in the refrigerator at subzero $20{ }^{\circ} \mathrm{C}$. Secondly, $900 \mu \mathrm{L}$ PBS was added into the spare tube to reach the concentration of $5 \mathrm{mg} / \mathrm{mL}$. Thirdly, after dilution ratio, six new $1.5 \mathrm{~mL}$ EP tubes were taken out and added into different capacities of PBS successively. Lastly, the concentrations of $\mathrm{PMB}$, in turn, were $1 \mathrm{mg} / \mathrm{mL}, 10,5,1$, $0.5,0.1 \mu \mathrm{g} / \mathrm{mL}$.

\section{Dilution of stock solution of Propofol medium and long chain fat emulsion injection}

The stock solution of Propofol medium and long chain fat emulsion injection $(10 \mathrm{mg} / \mathrm{mL})$ was dissolved and diluted with $0.1 \%$ DMSO and $\mathrm{pH} 6.0$ of PBS. Considering LPC has membrane toxicity (26) and British Pharmacopoeia (2013) shows that the limit of LPC is not more than $2 \mathrm{mg} / \mathrm{mL}$, so the concentration of LPC cannot too high. First, nine $1.5 \mathrm{~mL}$ EP tubes were taken out, and each tube was filled with Propofol medium and long chain fat emulsion injection of $1 \mathrm{ml}$. One tube was taken out for later use, and others were stored in the refrigerator at $4{ }^{\circ} \mathrm{C}$. Second, five new $1.5 \mathrm{~mL}$ EP tubes were taken out, then Propofol medium and long chain fat emulsion injection of $10 \mu \mathrm{L}$ was taken out from the spare tube, combined with $1 \%$ DMSO of $100 \mu \mathrm{L}$ and $890 \mu \mathrm{L}$ PBS to make the concentration of Propofol $100 \mu \mathrm{g} / \mathrm{mL}$. Third, the same amount of $1 \%$ DMSO of $100 \mu \mathrm{L}$ and different PBS capacities were added into the remaining four tubes from the dilution ratio. Last, the propofol concentrations were 50,10,5,1 $\mathrm{g} / \mathrm{mL}$.

\section{Specific details of the experiment}

All experiments were conducted by using the K-B method. The details of one test were: First, the aseptic dried circular filter paper was soaked in different concentrations $(10,5,1,0.5,0.1 \mu \mathrm{g} / \mathrm{mL})$ of $\mathrm{PMB}$ and different concentrations $(100,50,10,5,1 \mu \mathrm{g} / \mathrm{mL})$ of Propofol 

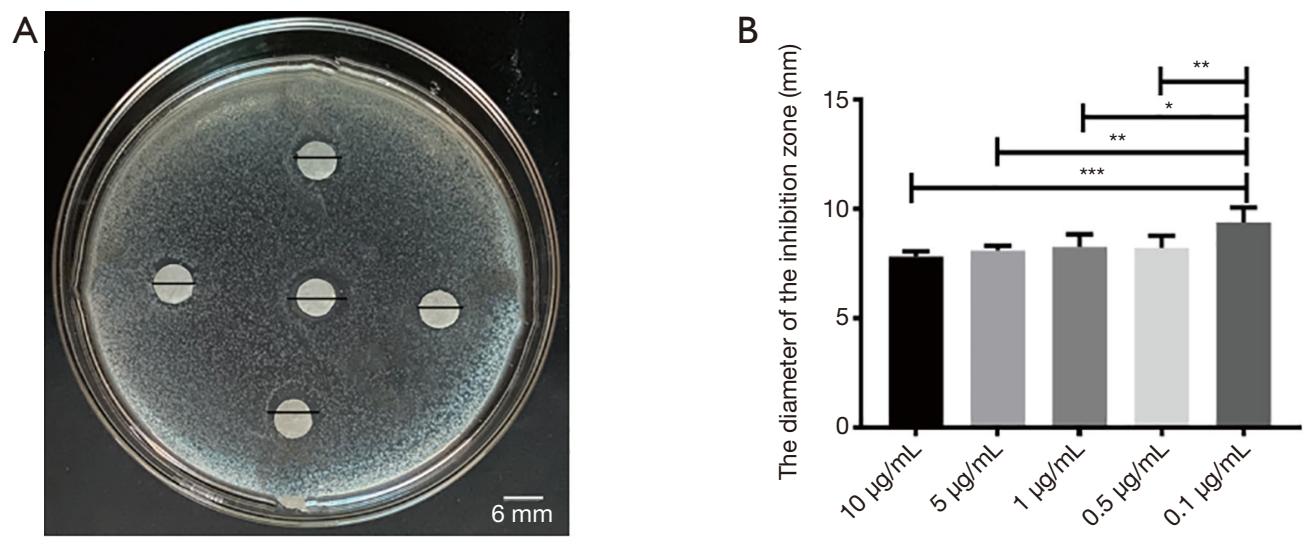

Figure 1 The bacteriostatic results of PMB. (A) Specific graphical representation of bacteriostasis of PMB: The diameter of inhibitory zone; (B) comparative analysis of the diameters of inhibitory zone produced by different concentrations of $\mathrm{PMB}$. *, $\mathrm{P}<0.05 ;{ }^{* *}, \mathrm{P}<0.01$; ${ }^{* * *}$, $\mathrm{P}<0.001$. PMB, Polymyxin B.

medium and long chain fat emulsion injection for 1 hour. Second, the bacterial liquid was coated evenly onto glass dishes, and these circular papers were put on them. Last, these glass dishes were inverted in the refrigerator at $4{ }^{\circ} \mathrm{C}$ for 2 hours, then incubated inverted at $37^{\circ} \mathrm{C}$ for 18 hours. The other test details were: the MIC of PMB, which the above tests had shown was mixed evenly with different Propofol medium and long chain fat emulsion injection concentrations. First, the aseptic dried circular filter paper was soaked in miscible liquid for 1 hour, Second, the bacterial liquid was coated evenly onto glass dishes, and these circular papers were put on them; Third, these glass dishes were inverted in the refrigerator at $4{ }^{\circ} \mathrm{C}$ for 2 hours and then inverted in an incubator at $37^{\circ} \mathrm{C}$ for 18 hours. It is worth noting the bacterial liquid must be evenly coated onto each glass dish, and the tweezers must be completely burned on the alcohol lamp when the circular paper was placed each time.

\section{The judgment of results}

All glass dishes were cultured for 18 hours, and then the diameters of the inhibitory zone were measured to determine the outcomes. The lowest drug concentration with the largest inhibitory zone diameter was the MIC of PMB and PMB combined with Propofol medium and long chain fat emulsion injection. All experiments were repeated six times.

\section{The processing and analysis of data}

Using GraphPad Prism 7 for statistical analysis, the inhibitory zone's diameters with different drug concentrations in the same group and the inhibitory zone's diameter with different drugs were evaluated by $t$-test. Data were considered statistically different at a $\mathrm{P}$ value of 0.05 or less.

\section{Results}

\section{The bacteriostatic results of $P M B$}

Using the K-B method to evaluate the bacteriostatic effect of PMB, the results were shown in Figure 1. Different concentrations of $\mathrm{PMB}$ all had bacteriostatic effects in Figure $1 \mathrm{~A}$. The diameter of an inhibitory zone with different $\mathrm{PMB}$ concentrations was evaluated by a $t$-test; it was found the differences only between the concentration $(0.1 \mu \mathrm{g} / \mathrm{mL})$ and others $(10,5,1,0.5 \mu \mathrm{g} / \mathrm{mL})$ were statistically significant in Figure $1 B$.

\section{The bacteriostatic results of Propofol medium and long chain fat emulsion injection}

Using the K-B method to evaluate the bacteriostatic effect of Propofol medium and long chain fat emulsion injection, the results were shown in Figure 2. Different concentrations of Propofol medium and long chain fat emulsion injection did not have bacteriostatic effects in Figure $2 A$. The diameters of the inhibitory zone with different concentrations of Propofol medium and long chain fat emulsion injection were evaluated by $t$-test; it was found that all differences were not statistically significant in Figure $2 B$. 

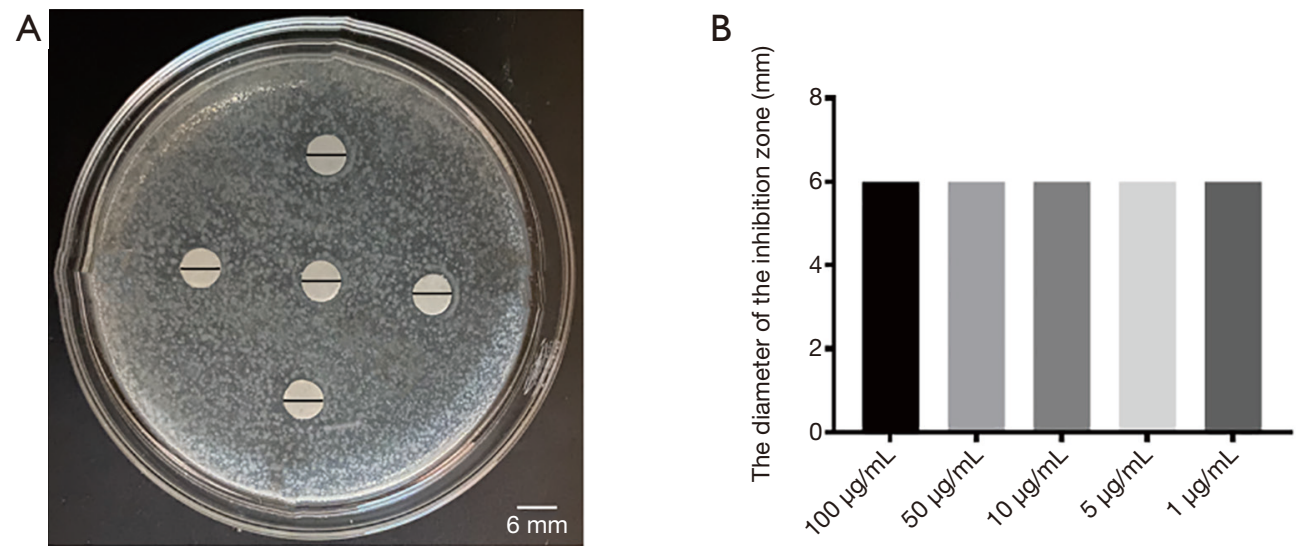

Figure 2 The bacteriostatic results of Propofol medium and long chain fat emulsion injection. (A) Specific graphical representation of bacteriostasis of Propofol medium and long chain fat emulsion injection: The diameter of inhibitory zone; (B) comparative analysis of the diameters of inhibitory zone produced by different concentrations of Propofol medium and long chain fat emulsion injection.
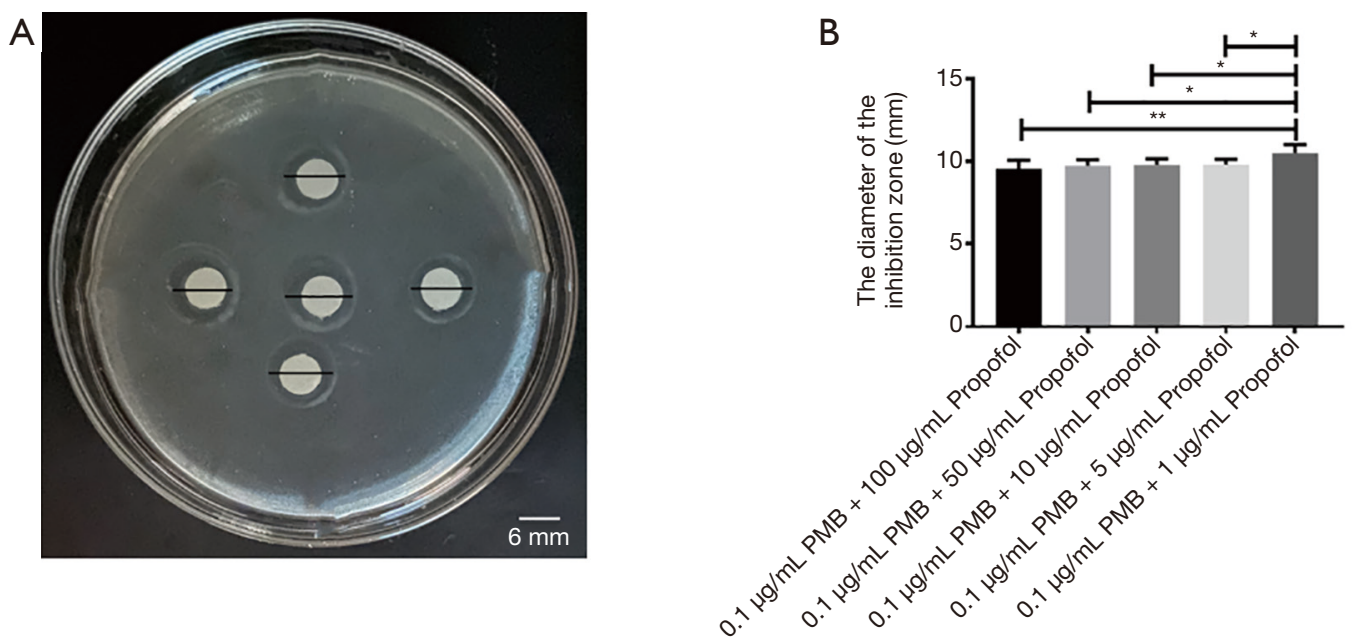

Figure 3 The bacteriostatic results of PMB $(0.1 \mu \mathrm{g} / \mathrm{mL})$ combined with different concentrations of Propofol. (A) Specific graphical representation of bacteriostasis of PMB $(0.1 \mu \mathrm{g} / \mathrm{mL})$ combined with different concentrations of Propofol: the diameter of inhibitory zone; (B) comparative analysis of the diameters of inhibitory zone produced by PMB $(0.1 \mu \mathrm{g} / \mathrm{mL})$ combined with different concentrations of Propofol. *, $\mathrm{P}<0.05$; **, $\mathrm{P}<0.01$. PMB, Polymyxin $\mathrm{B}$; Propofol, Propofol medium and long chain fat emulsion injection.

\section{The bacteriostatic results of PMB $(0.1 \mu \mathrm{g} / \mathrm{mL})$ combined with different concentrations of Propofol medium and long chain fat emulsion injection}

Using the K-B method to evaluate the bacteriostatic effect of PMB combined with Propofol medium and long chain fat emulsion injection, the results were shown in Figure 3. The PMB $(0.1 \mu \mathrm{g} / \mathrm{mL})$ combined with different concentrations of Propofol medium and long chain fat emulsion injection all had bacteriostatic effects in Figure $3 \mathrm{~A}$.
The inhibitory zone diameter with the PMB $(0.1 \mu \mathrm{g} / \mathrm{mL})$ combined with different concentrations of Propofol medium and long chain fat emulsion injection was tested by $t$-test. It was found the difference only between the concentration [the combination of PMB $(0.1 \mu \mathrm{g} / \mathrm{mL})$ with Propofol $(1 \mu \mathrm{g} / \mathrm{mL})$ ] and others [the combination of PMB $(0.1 \mu \mathrm{g} / \mathrm{mL})$ with Propofol $(100 \mu \mathrm{g} / \mathrm{mL})$, the combination of PMB $(0.1 \mu \mathrm{g} / \mathrm{mL})$ with Propofol $(50 \mu \mathrm{g} / \mathrm{mL})$, the combination of PMB $(0.1 \mu \mathrm{g} / \mathrm{mL})$ with Propofol $(10 \mu \mathrm{g} / \mathrm{mL})$, the combination of PMB $(0.1 \mu \mathrm{g} / \mathrm{mL})$ with Propofol 


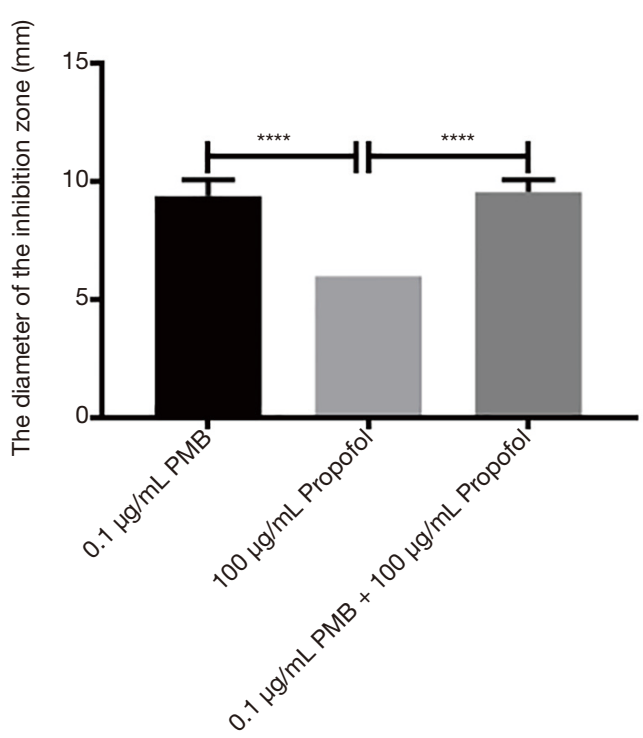

Figure 4 Comparative analysis of the diameters of inhibitory zone of PMB $(0.1 \mu \mathrm{g} / \mathrm{mL})$, Propofol $(100 \mu \mathrm{g} / \mathrm{mL})$ and the combination of two drugs. ****, $\mathrm{P}<0.0001$. PMB, Polymyxin B; Propofol, Propofol medium and long chain fat emulsion injection.

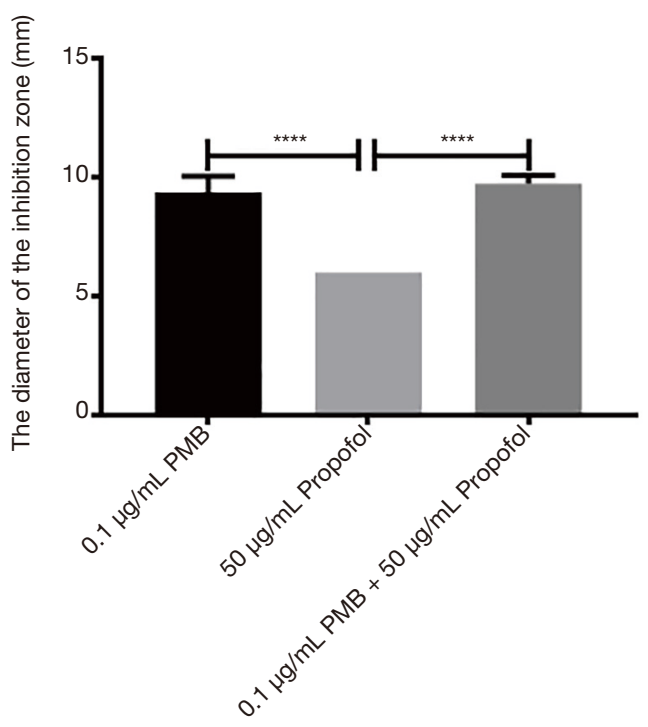

Figure 5 Comparative analysis of the diameters of inhibitory zone of PMB $(0.1 \mu \mathrm{g} / \mathrm{mL})$, Propofol $(50 \mu \mathrm{g} / \mathrm{mL})$ and the combination of two drugs. ****, $\mathrm{P}<0.0001$. PMB, Polymyxin B; Propofol, Propofol medium and long chain fat emulsion injection.
$(5 \mu \mathrm{g} / \mathrm{mL})]$ were statistically significant in Figure $3 B$.

The analysis of the diameter of the inhibitory zone of PMB $(0.1 \mu \mathrm{g} / \mathrm{mL})$, propofol (100 $\mu \mathrm{g} / \mathrm{mL})$, and the combination of two drugs

It was found the differences between propofol $(100 \mu \mathrm{g} / \mathrm{mL})$ and PMB $(0.1 \mu \mathrm{g} / \mathrm{mL})$ or the combination of PMB $(0.1 \mu \mathrm{g} / \mathrm{mL})$ with propofol $(100 \mu \mathrm{g} / \mathrm{mL})$ were statistically significant in the diameter's analysis of an inhibitory zone by $t$-test. However, the difference between PMB $(0.1 \mu \mathrm{g} / \mathrm{mL})$ and the combination of PMB $(0.1 \mu \mathrm{g} / \mathrm{mL})$ with propofol $(100 \mu \mathrm{g} / \mathrm{mL})$ was not statistically significant in Figure 4.

The analysis of the diameter of the inbibitory zone of $P M B$ $(0.1 \mu \mathrm{g} / \mathrm{mL})$, propofol $(50 \mu \mathrm{g} / \mathrm{mL})$, and the combination of two drugs

It was found the differences between propofol $(50 \mu \mathrm{g} /$ $\mathrm{mL})$ and PMB $(0.1 \mu \mathrm{g} / \mathrm{mL})$ or the combination of PMB $(0.1 \mu \mathrm{g} / \mathrm{mL})$ with propofol $(50 \mu \mathrm{g} / \mathrm{mL})$ were statistically significant in the diameter's analysis of an inhibitory zone by $t$-test. However, the difference between PMB $(0.1 \mu \mathrm{g} / \mathrm{mL})$ and the combination of PMB $(0.1 \mu \mathrm{g} / \mathrm{mL})$ with propofol $(50 \mu \mathrm{g} / \mathrm{mL})$ was not statistically significant in Figure 5 .

The analysis of the diameters of the inbibitory zone of PMB $(0.1 \mu \mathrm{g} / \mathrm{mL})$, propofol $(10 \mu \mathrm{g} / \mathrm{mL})$, and the combination of two drugs

It was found the differences between propofol $(10 \mu \mathrm{g} /$ $\mathrm{mL})$ and $\mathrm{PMB}(0.1 \mu \mathrm{g} / \mathrm{mL})$ or the combination of $\mathrm{PMB}$ $(0.1 \mu \mathrm{g} / \mathrm{mL})$ with propofol $(10 \mu \mathrm{g} / \mathrm{mL})$ were statistically significant in the diameter's analysis of an inhibitory zone by $t$-test. However, the difference between PMB $(0.1 \mu \mathrm{g} / \mathrm{mL})$ and the combination of PMB $(0.1 \mu \mathrm{g} / \mathrm{mL})$ with propofol $(10 \mu \mathrm{g} / \mathrm{mL})$ was not statistically significant in Figure 6.

\section{The analysis of the diameters of the inhibitory zone of PMB $(0.1 \mu \mathrm{g} / \mathrm{mL})$, propofol $(5 \mu \mathrm{g} / \mathrm{mL})$, and the combination of two drugs}

It was found the differences between propofol $(5 \mu \mathrm{g} / \mathrm{mL})$ and 


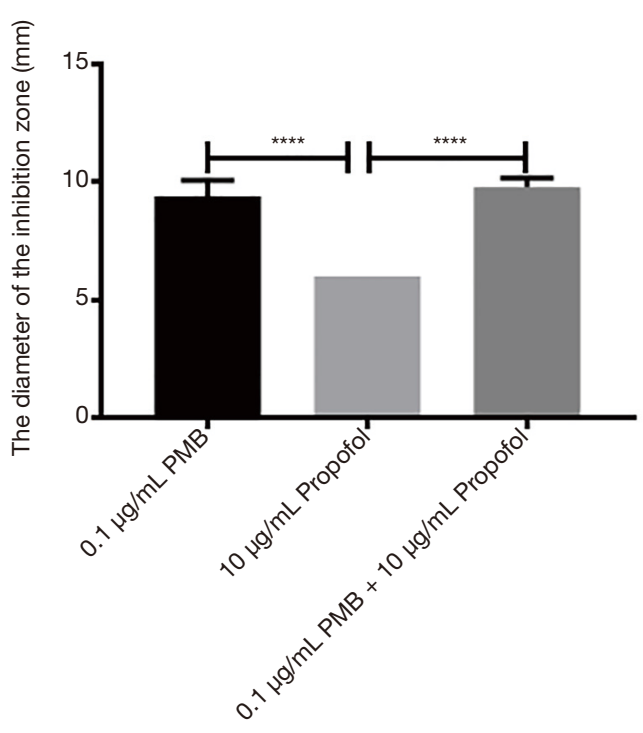

Figure 6 Comparative analysis of the diameters of inhibitory zone of PMB $(0.1 \mu \mathrm{g} / \mathrm{mL})$, Propofol $(10 \mu \mathrm{g} / \mathrm{mL})$ and the combination of two drugs. ****, $\mathrm{P}<0.0001$. PMB, Polymyxin B; Propofol, Propofol medium and long chain fat emulsion injection.

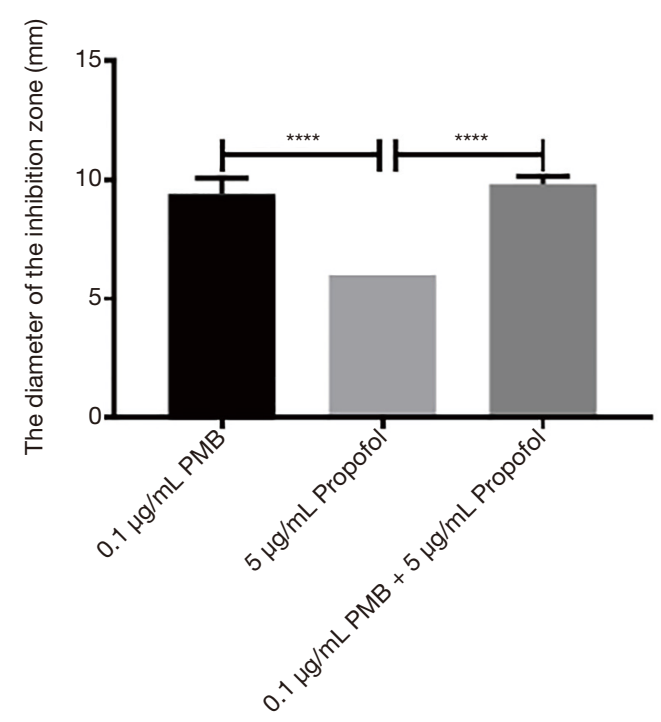

Figure 7 Comparative analysis of the diameters of inhibitory zone of PMB $(0.1 \mu \mathrm{g} / \mathrm{mL})$, Propofol $(5 \mu \mathrm{g} / \mathrm{mL})$ and the combination of two drugs. ***, $\mathrm{P}<0.0001$. PMB, Polymyxin B; Propofol, Propofol medium and long chain fat emulsion injection.

PMB $(0.1 \mu \mathrm{g} / \mathrm{mL})$ or the combination of PMB $(0.1 \mu \mathrm{g} / \mathrm{mL})$ with propofol $(5 \mu \mathrm{g} / \mathrm{mL})$ were statistically significant in the diameter's analysis of an inhibitory zone by $t$-test.

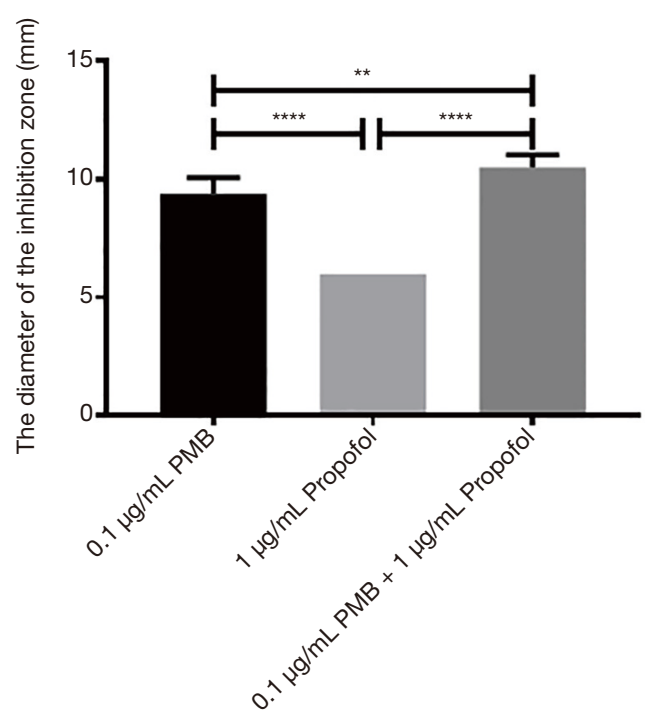

Figure 8 Comparative analysis of the diameters of inhibitory zone of PMB $(0.1 \mu \mathrm{g} / \mathrm{mL})$, Propofol $(1 \mu \mathrm{g} / \mathrm{mL})$ and the combination of two drugs. **, $\mathrm{P}<0.01$; ${ }^{* * *}, \mathrm{P}<0.0001$. $\mathrm{PMB}$, Polymyxin $\mathrm{B}$; Propofol, Propofol medium and long chain fat emulsion injection.

However, the difference between PMB $(0.1 \mu \mathrm{g} / \mathrm{mL})$ and the combination of PMB $(0.1 \mu \mathrm{g} / \mathrm{mL})$ with propofol $(5 \mu \mathrm{g} / \mathrm{mL})$ was not statistically significant in Figure 7.

The analysis of the diameter of the inhibitory zone of PMB $(0.1 \mu \mathrm{g} / \mathrm{mL})$, propofol $(1 \mu \mathrm{g} / \mathrm{mL})$, and the combination of two drugs

It was found the differences between propofol $(1 \mu \mathrm{g} / \mathrm{mL})$ and PMB $(0.1 \mu \mathrm{g} / \mathrm{mL})$ or the combination of PMB $(0.1 \mu \mathrm{g} / \mathrm{mL})$ with propofol $(1 \mu \mathrm{g} / \mathrm{mL})$ were statistically significant in the diameter's analysis of an inhibitory zone by $t$-test. Meanwhile, the difference between PMB $(0.1 \mu \mathrm{g} / \mathrm{mL})$ and the combination of PMB $(0.1 \mu \mathrm{g} / \mathrm{mL})$ with propofol $(1 \mu \mathrm{g} / \mathrm{mL})$ was statistically significant in Figure 8.

\section{Discussion}

Nowadays, despite advances in emergency and critical care medicine, the number of Sepsis cases is increasing dramatically, and the incidence of Septic shock is also gradually rising. Furthermore, the mortality rate of septic shock is still at an elevated level; thus, more and more attention has been paid to the treatment of sepsis all over the world (27). It is currently considered sepsis results from a series of inflammatory mediators that cause a systemic 
inflammatory response to be out of control, and endotoxin is the main factor of the septic systemic inflammatory response (28). As we all know, endotoxin is a component of the cell wall of Gram-negative bacilli (GNB) and a toxin component, constantly released in the process of bacterial reproduction. Besides its toxicity, free endotoxin is also a strong stimulating factor that can stimulate various cells to produce a series of inflammatory mediators. These inflammatory mediators can interact to form a network reaction known as "Waterfall Reaction" (29). The above reactions make the inflammatory response expand infinitely until it gets out of control, resulting in a systemic inflammatory response characterized by the body cells' self-destruction. PMB can interact with lipid A, the outer membrane lipopolysaccharide (LPS) component of Gramnegative bacteria, neutralize its endotoxin activity, and antagonize its biological effects endotoxin (30). Besides its routine hypnotic and sedative anesthetic efficacy, Propofol medium and long chain fat emulsion injection has gradually been found to have anti-inflammatory effects. At present, it has been proved propofol can exert anti-inflammatory and cytoprotective effects by restraining many aspects of the inflammatory response, including inhibiting the release of inflammatory cytokines, increasing the expression of antioxidant proteins, preventing the aggregation of neutrophils, improving microcirculation, reducing the synthesis of NO and so on (19). Tyner et al. (31) found that propofol's intravenous injection could significantly promote skin flaps' survival in the rat model; this discovery's possible mechanism is propofol inhibited the inflammatory response caused by neutrophils around the skin flaps. This successful experimental study suggests propofol functions, including preventing oxidation, inhibiting neutrophils' over-activation, and restraining the inflammatory response, have clinical application value.

Due to the combination of PMB with Propofol medium and long chain fat emulsion injection is novel and brandnew, no literature has researched. In this study, we have already evaluated the synergistic bacteriostatic effect of PMB combined with Propofol medium and long chain fat emulsion injection against Escherichia coli in vitro. Then, we can continue to evaluate the synergistic bacteriostatic effect of two drugs against Escherichia coli in vivo. Also, we should continue to study and explore the application and related mechanisms of PMB combined with Propofol medium and long chain fat emulsion injection in Sepsis to supply innovative ideas for the anti-inflammatory correlation of systemic inflammatory response syndrome
(SIRS), caused by Sepsis.

\section{Conclusions}

In this study, the Minimal Inhibitory Concentration of PMB combined with Propofol medium and long chain fat emulsion injection and two drugs used alone against Escherichia coli were detected with K-B method, and the diameters of the inhibition zone were calculated to evaluate bacteriostatic effects. The results were: the MIC of PMB against Escherichia coli was $0.1 \mu \mathrm{g} / \mathrm{mL}$, which had the largest diameter of the inhibitory zone, and Propofol medium and long chain fat emulsion injection does not have an obvious bacteriostatic effect on Escherichia coli. The MIC of PMB combined with Propofol medium and long chain fat emulsion injection against Escherichia coli was PMB $(0.1 \mu \mathrm{g} / \mathrm{mL})$ combined with Propofol medium and long chain fat emulsion injection $(1 \mu \mathrm{g} / \mathrm{mL})$, which had the largest diameter of the inhibitory zone. Therefore, whether PMB alone or PMB combined with Propofol medium and long chain fat emulsion injection have a suitable bacteriostatic effect on common clinical Gram-negative Enterobacillus in vitro. Meanwhile, it also showed the bacteriostatic effect of the combination of PMB with Propofol medium and long chain fat emulsion injection against Escherichia coli was synergistic, and no effect of uncorrelated and antagonism was observed in this combination. Thus, the combination of the two drugs can synergistically expand the bacteriostatic effect of a single drug. Relevant literature (22) indicates that Propofol medium and long chain fat emulsion injection contains LPC, and related data (17) shows PMB with LPC finally causes the bacterial cell membrane collapse, further resulting in bacterial death. We can consider the basic mechanism of this experiment as described above. Therefore, PMB combined with Propofol medium and long chain fat emulsion injection can treat Gram-negative Enterobacter infection in clinical practice. However, it is worth noting some reports have suggested polymyxins can damage the kidney and nervous system of the human body (32), so significant doses of long-term use should be avoided so as not to affect the basic physiological functions of the human body.

\section{Acknowledgments}

Funding: This study was supported by the National Natural Science Foundation of China Youth (81801893), the Nantong Clinical Medicine Research Center (HS2019005 
and HS2020001), and the Nantong scientific projects (MS12020006 and MS12020017).

\section{Footnote}

Reporting Checklist: The authors have completed the MDAR reporting checklist. Available at http://dx.doi.org/10.21037/ apm-21-751

Data Sharing Statement: Available at http://dx.doi. org/10.21037/apm-21-751

Conflicts of Interest: All authors have completed the ICMJE uniform disclosure form (available at http://dx.doi. org/10.21037/apm-21-751). The authors have no conflicts of interest to declare.

Ethical Statement: The authors are accountable for all aspects of the work in ensuring that questions related to the accuracy or integrity of any part of the work are appropriately investigated and resolved.

Open Access Statement: This is an Open Access article distributed in accordance with the Creative Commons Attribution-NonCommercial-NoDerivs 4.0 International License (CC BY-NC-ND 4.0), which permits the noncommercial replication and distribution of the article with the strict proviso that no changes or edits are made and the original work is properly cited (including links to both the formal publication through the relevant DOI and the license). See: https://creativecommons.org/licenses/by-nc-nd/4.0/.

\section{References}

1. Manohar P, Shanthini T, Ayyanar R, et al. The distribution of carbapenem- and colistin-resistance in Gram-negative bacteria from the Tamil Nadu region in India. J Med Microbiol 2017;66:874-83.

2. Luepke KH, Suda KJ, Boucher H, et al. Past, Present, and Future of Antibacterial Economics: Increasing Bacterial Resistance, Limited Antibiotic Pipeline, and Societal Implications. Pharmacotherapy 2017;37:71-84.

3. Nachimuthu R, Subramani R, Maray S, et al. Characterization of carbapenem-resistant Gram-negative bacteria from Tamil Nadu. J Chemother 2016;28:371-4.

4. Jean SS, Lee WS, Bai KJ, et al. Carbapenem susceptibility among Escherichia coli, Klebsiella pneumoniae, and Enterobacter cloacae isolates obtained from patients in intensive care units in Taiwan in 2005, 2007, and 2009. Diagn Microbiol Infect Dis 2015;81:290-5.

5. Vasoo S, Barreto JN, Tosh PK. Emerging issues in gramnegative bacterial resistance: an update for the practicing clinician. Mayo Clin Proc 2015;90:395-403.

6. Li J, Nation RL, Milne RW, et al. Evaluation of colistin as an agent against multi-resistant Gram-negative bacteria. Int J Antimicrob Agents 2005;25:11-25.

7. Hagihara M, Housman ST, Nicolau DP, et al. In vitro pharmacodynamics of polymyxin B and tigecycline alone and in combination against carbapenem-resistant Acinetobacter baumannii. Antimicrob Agents Chemother 2014;58:874-9.

8. Lim TP, Lee W, Tan TY, et al. Effective antibiotics in combination against extreme drug-resistant Pseudomonas aeruginosa with decreased susceptibility to polymyxin B. PLoS One 2011;6:e28177.

9. Jernigan MG, Press EG, Nguyen MH, et al. The combination of doripenem and colistin is bactericidal and synergistic against colistin-resistant, carbapenemaseproducing Klebsiella pneumoniae. Antimicrob Agents Chemother 2012;56:3395-8.

10. Zavascki AP, Goldani LZ, Li J, et al. Polymyxin B for the treatment of multidrug-resistant pathogens: a critical review. J Antimicrob Chemother 2007;60:1206-15.

11. Bhor VM, Thomas CJ, Surolia N, et al. Polymyxin B: an ode to an old antidote for endotoxic shock. Mol Biosyst 2005;1:213-22.

12. Zgurskaya HI, Lopez CA, Gnanakaran S. Permeability Barrier of Gram-Negative Cell Envelopes and Approaches To Bypass It. ACS Infect Dis 2015;1:512-22.

13. Nishino K, Hsu FF, Turk J, et al. Identification of the lipopolysaccharide modifications controlled by the Salmonella PmrA/PmrB system mediating resistance to Fe(III) and Al(III). Mol Microbiol 2006;61:645-54.

14. Hancock RE. Antibacterial peptides and the outer membranes of gram-negative bacilli. J Med Microbiol 1997;46:1-3.

15. Hancock RE, Lehrer R. Cationic peptides: a new source of antibiotics. Trends Biotechnol 1998;16:82-8.

16. Velkov T, Roberts KD, Thompson PE, et al. Polymyxins: a new hope in combating Gram-negative superbugs? Future Med Chem 2016;8:1017-25.

17. Yadav J, Ismaeel S, Qadri A. Lysophosphatidylcholine Potentiates Antibacterial Activity of Polymyxin B. Antimicrob Agents Chemother 2020;64:e01337-20.

18. Kanto J, Gepts E. Pharmacokinetic implications for the clinical use of propofol. Clin Pharmacokinet 
1989;17:308-26.

19. Marik PE. Propofol: therapeutic indications and sideeffects. Curr Pharm Des 2004;10:3639-49.

20. Ohmizo H, Obara S, Iwama H. Mechanism of injection pain with long and long-medium chain triglyceride emulsive propofol. Can J Anaesth 2005;52:595-9.

21. Parks CL, Tucker W, Amlong CA, et al. Lipid-free Fluoropolymer-based Propofol Emulsions and Lipid Reversal of Propofol Anesthesia in Rats. Anesthesiology 2016;124:1328-37.

22. Baker MT, Naguib M. Propofol: the challenges of formulation. Anesthesiology 2005;103:860-76.

23. Nassar MSM, Hazzah WA, Bakr WMK. Evaluation of antibiotic susceptibility test results: how guilty a laboratory could be? J Egypt Public Health Assoc 2019;94:4.

24. Joseph NM, Sistla S, Dutta TK, et al. Reliability of KirbyBauer disk diffusion method for detecting meropenem resistance among non-fermenting gram-negative bacilli. Indian J Pathol Microbiol 2011;54:556-60.

25. Gales AC, Reis AO, Jones RN. Contemporary assessment of antimicrobial susceptibility testing methods for polymyxin B and colistin: review of available interpretative criteria and quality control guidelines. J Clin Microbiol 2001;39:183-90.

26. Martin GP, el-Hariri LM, Marriott C. Bile salt-

Cite this article as: Qi L, Wang Y, Chen B, Ren Y, Mao G, Liang G, Liu W, Zhou Y, Huang Z, Sun K, Jiang H. In vitro bacteriostatic effects of Polymyxin B combined with Propofol medium and long chain fat emulsion injection against Escherichia coli. Ann Palliat Med 2021;10(4):4687-4696. doi: 10.21037/ apm-21-751 and lysophosphatidylcholine-induced membrane damage in human erythrocytes. J Pharm Pharmacol 1992;44:646-50.

27. Cauwels A, Bultinck J, De Zwaef R, et al. Nitric oxide production by endotoxin preparations in TLR4-deficient mice. Nitric Oxide 2014;36:36-43.

28. Salomão R, Ferreira BL, Salomao MC, et al. Sepsis: evolving concepts and challenges. Braz J Med Biol Res 2019;52:e8595.

29. Wang H, Bloom O, Zhang M, et al. HMG-1 as a late mediator of endotoxin lethality in mice. Science 1999;285:248-51.

30. Gough M, Hancock RE, Kelly NM. Antiendotoxin activity of cationic peptide antimicrobial agents. Infect Immun 1996;64:4922-7.

31. Tyner TR, Shahbazian R, Nakashima J, et al. Propofol improves skin flap survival in a rat model: correlating reduction in flap-induced neutrophil activity. Ann Plast Surg 2004;53:273-7.

32. Rabanal F, Cajal Y. Recent advances and perspectives in the design and development of polymyxins. Nat Prod Rep 2017;34:886-908.

(English Language Editor: J. Chapnick) 